\title{
Granulomatous Syphilis: A Pattern to Remember. Case Report and Review of Literature
}

Grace L. Lee ${ }^{1}$, Alejandro A Gru ${ }^{1,2}$, Henry K Wong ${ }^{1}$ and Priyadharsini Nagarajan ${ }^{3 *}$

${ }^{1}$ Division of Dermatology, Department of Internal Medicine, The Ohio State University-Wexner Medical Center, Columbus, OH, USA

${ }^{2}$ Department of Pathology, The Ohio State University-Wexner Medical Center, Columbus, OH, USA

${ }^{3}$ Department of Pathology, Section of Dermatopathology, University of Texas MD Anderson Cancer Center, Houston, TX, USA

\begin{abstract}
Granulomatous inflammation in secondary syphilis is rare and poses diagnostic challenges both on clinical grounds and histologically. We report a case of granulomatous syphilis in a 44-year-old woman that presented with an erythematous papulo-nodular rash involving her face, neck and upper portions of chest, back and arms that was initially diagnosed as urticaria and treated ineffectively with systemic steroids. No mucosal or genital lesions, involvement of soles and palms, or lymphadenopathy was present. Histopathologic examination revealed dense dermal perivascular and periadnexal inflammatory infiltrate composed of lymphocytes and plasma cells accompanied by prominent granulomatous inflammation. Anti-treponemal immunohistochemical study revealed spirochetes and along with positive serology, supporting the diagnosis of secondary syphilis. With an increasing number of reported syphilis cases recently, internists, infectious disease specialists, dermatologists and dermatopathologists alike should be aware of the unusual presentations of this great imitator. We also present a review of literature of cases of secondary syphilis that present in such unusual clinical and histologic phenotypes.
\end{abstract}

Keywords: Granulomatous; Syphilis; Atypical

\section{Introduction}

The incidence of syphilis, a sexually transmitted disease caused by Treponema pallidum subsp. pallidum is on the rise in the United States [1]. After an all-time low of 2.1 cases of primary and secondary syphilis per 100,000 population in 2000 [2], there has been a steady increase in the number of reported cases of syphilis [3]. In 2013, 16,663 cases of primary and secondary syphilis were reported, with a rate of 5.3 cases per 100,000 . While more than $90 \%$ of the syphilis cases are reported in men, the number of women affected by the disease has been slowly decreasing.

The incidence of primary syphilis is very likely to be underreported since most patients are frequently asymptomatic and are unaware of the presence of the asymptomatic chancre, particularly in the absence of secondary infections. About a fourth of the untreated patients with primary syphilis fail to clear the infection and proceed to the secondary stage $[4,5]$. The clinical manifestations of secondary syphilis consist of non-specific symptoms (fever, headache, malaise and weight loss), but also typical findings including maculo-papular skin rash, lymphadenopathy, condyloma lata, and mucosal ulcers [6]. Systemic manifestations such as uveitis, retinitis, alopecia, arthritis, osteitis, meningitis, cranial neuropathies, glomerulonephritis, and hepatitis may also be seen. Though the most common skin rash is the maculopapular eruption, in some patients, the cutaneous involvement can be quite varied, leading to difficulties with clinical recognition $[7,8]$. Here, we report a case of atypical secondary syphilis in a 44-year-old woman that was initially diagnosed as urticaria.

\section{Case Report}

A 44-year-old Caucasian woman presented with a 4-week history of generalized painful rash, malaise, and myalgia. The rash initially began on her face as asymptomatic, small, pink lesions which then spread caudally to her neck, chest, upper back, and proximal extremities. She had initially been diagnosed with acute urticaria and was treated with systemic steroids an outside facility. However, the rash persisted, continued to progress and eventually also became tender. Physical examination revealed multiple edematous and indurated pink papules, which in some areas coalesced to form plaques and small nodules, involving her face, anterior neck, upper chest, bilateral lateral upper arms, and upper back (Figure 1A-1D). No scale or crust was present. There were no oral ulcers, genital lesions or palmar and plantar rash or lymphadenopathy. She also complained of generalized malaise, fever, chills, arthralgia, and recent unintended 10-pound weight loss. Based on the clinical presentation, the differential diagnosis included cutaneous lupus erythematous, Sweet's syndrome, cutaneous T-cell lymphoma, scleromyxedema, HIV and secondary syphilis.

A punch biopsy was performed on one of her left upper arm lesions, which revealed superficial and deep dermal predominantly perivascular and periadnexal inflammatory infiltrate (Figure 2A). Though the inflammatory infiltrate extended to the superficial subcutaneous adipose tissue, frank panniculitis was not seen. Within the deep dermis, there was an accentuation of the inflammatory infiltrate around several small caliber nerve fibers (data not shown). There was focal interface dermatitis with vacuolar changes of the basal keratinocytes and lymphocyte exocytosis (Figure 2B). The epidermis was slightly acanthotic with mild hyperkeratosis. An obvious Grenz zone was not observed. The inflammatory infiltrate was composed predominantly of epithelioid histiocytes with abundant amounts of pale eosinophilic cytoplasm and small ovoid nuclei, admixed

*Corresponding author: Priyadharsini Nagarajan, Department of Pathology, Section of Dermatopathology, University of Texas MD Anderson Cancer Center, 1515 Holcombe Blvd, Unit 85, Houston, TX 77030, Tel: 713-745-2367, E-mail: pnagarajan@mdanderson.org

Received December 12, 2014; Accepted January 26, 2015; Published February 05, 2015

Citation: Lee GL, Gru AA, Wong HK, Nagarajan P (2015) Granulomatous Syphilis: A Pattern to Remember. Case Report and Review of Literature. Clin Microbial 4: 184. doi:10.4172/2327-5073.1000184

Copyright: ( 2015 Lee GL, et al. This is an open-access article distributed under the terms of the Creative Commons Attribution License, which permits unrestricted use, distribution, and reproduction in any medium, provided the original author and source are credited. 
Citation: Lee GL, Gru AA, Wong HK, Nagarajan P (2015) Granulomatous Syphilis: A Pattern to Remember. Case Report and Review of Literature. Clin Microbial 4: 184. doi:10.4172/2327-5073.1000184
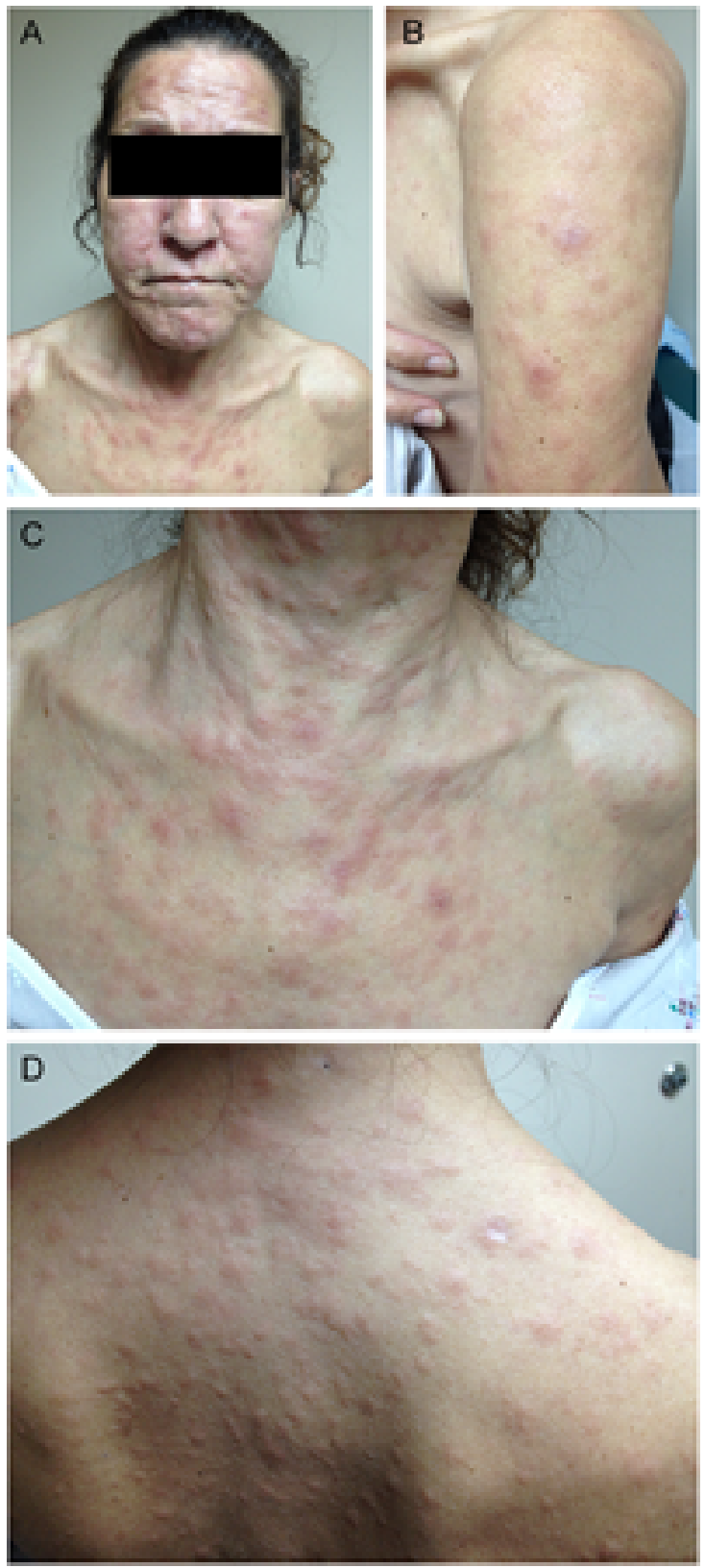

Figure 1: Clinical appearance. Multiple, erythematous non-scaly papules plaques and small nodules involving the $(A)$ face, $(B)$ upper arms, $(C)$ anterior neck and upper chest, and (D) upper back.

with multinucleated histiocytes, lymphocytes and scattered plasma cells and eosinophils. Some of the blood vessels surrounded by the granulomatous inflammatory infiltrate demonstrated vascular endothelial swelling, and mononuclear lymphocytes could be identified within the thickened vessel walls (Figure $2 \mathrm{C}, \mathrm{D}$ ). In some of these foci, the blood vessel could not be identified and was replaced by fibrin and admixed with karyorrhectic cellular debris. Special stains were negative for acid fast bacilli and a Warthin-Starry stain failed to reveal unequivocal spirochetal organisms. A specimen was also sent to the Center for Disease Control and Prevention and an immunofluorescence study using anti-treponemal antibody revealed multiple spirochetes, confirming the diagnosis of secondary syphilis (data not shown).
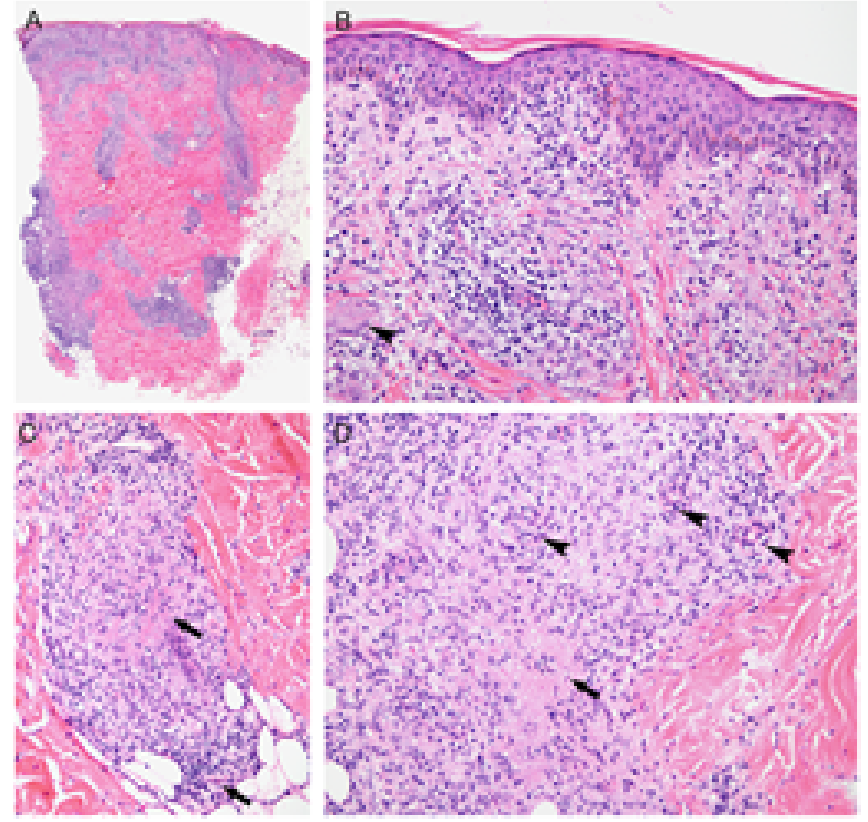

Figure 2: Histopathologic features. Hematoxylin and eosin stained sections show (A) a superficial and deep dermal perivascular and periadnexal inflammatory infiltrate. (B) There is a mild interface dermatitis and perivascular lymphohistiocytic infiltrate with occasional multinucleated histiocytes (arrowhead). Perivascular granulomatous infiltrate with central fibrinous exudate and cellular debris (upper arrow); scattered eosinophils are also seen (lower arrow). (D) Endothelial swelling and mononuclear cells within vesse walls (arrowheads) and prominent fibrinous exudate around an inconspicuous vessel. Magnifications: A- 40x, B-D- 200x.

She ultimately admitted to intravenous drug abuse and engaging in unprotected sexually activity with her ex-husband during the past one year. She also recalled painful vaginal and oral lesions a while ago that had resolved by the time the rash erupted. An extensive laboratory work up including complete blood count, comprehensive metabolic panel, and serologic studies for anti-Smith, anti-RNP, anti-SSA, antiSSB, anti-dsDNA antibodies, rapid plasma reagin (RPR), syphilis IgG antibody, and HIV serology was performed. All tests were within normal limits except for positive syphilis IgG antibody and RPR titer of 1:512. She was treated with one dose $2.4 \mathrm{M}$ units of benzathine penicillin intramuscularly. A day later, she developed sudden left-sided loss of vision and mental status changes and was diagnosed with left-sided anterior uveitis. A cerebrospinal fluid serology was performed and was found to be negative for neurosyphilis. Nevertheless, the patient received treatment with intravenous $4 \mathrm{M}$ units of aqueous crystalline penicillin $\mathrm{G}$, every 4 hours for 14 days. The patient's neurologic symptoms were eventually attributed to her abusing pregabalin, diphenhydramine, and tramadol. Her skin rash had improved significantly on follow-up visit 2 weeks after discharge from the hospital. The visual loss in her left eye was improving at follow-up with her ophthalmologist, while conjunctival injection, pain and burning sensation had completely subsided.

\section{Discussion}

Syphilis, particularly in its secondary stage has been notoriously referred to as the great imitator. The myriad clinical presentations of syphilis have been extensively documented in the past centuries. With the advent of antibiotics and more recently the HIV control programs, there was an overall decrease in the incidence of the disease towards 
the turn of last century. With decreasing numbers of syphilis cases, the varied clinical phenotypes have been largely forgotten. However, during the past decade or so, there has been a steady rise in the number of reported cases of syphilis, especially in specific populations $[1,2]$. Moreover, this re-emerging infection, while not being in the list of common diagnoses, may present with unusual clinical and histologic phenotypes, making it a diagnostic challenge, particularly in low-risk populations.

Secondary syphilis usually develops 30 to 90 days after the appearance of chancre [9], and the most common presentation includes generalized skin rash, mucosal lesions and generalized or localized lymphadenopathy and is often associated with fever, malaise and weight loss [6]. Typical skin rash of early secondary syphilis include macular, small papular, follicular (pseudovesicular), lichenoid, vesicular, psoriasiform and corymbiform rashes [7]. Late secondary syphilis may present with large papules, condylomata lata, hypertrophic papules (frambesiform lesions) and also pustular, annular and rarely (ulcerating) nodular lesions. The cutaneous lesions are usually symmetrical with frequent facial involvement.

Granulomatous inflammation is a hallmark of tertiary syphilis, which also presents with massive caseating necrosis [10-13]. Though uncommon, a prominent histiocytic inflammatory infiltrate has been described in lesions of secondary syphilis as well [11,14-17]. In most cases, the presence of mucosal ulcerations, involvement of palms and soles as well as genital lesions is usually the tip-off that raises the possibility of syphilis. In the absence of these hints, clinical diagnosis of atypical secondary syphilis can be challenging and in multiple instances, the patients may be treated for other diseases unsuccessfully.

The clinical differential diagnoses for a widespread erythematous, indurated papulo-nodular skin eruption is often long and comprises of cutaneous lymphoid hyperplasia, Sweet's syndrome, lymphoproliferative diseases (primary cutaneous lymphomas, secondary cutaneous involvement by a systemic lymphoma, leukemia cutis); other neoplasms including histiocytoses, metastatic melanoma or carcinoma; infections such as lepromatous leprosy, other mycobacterial infections and disseminated deep fungal infections; granulomatous processes such as disseminated granuloma annulare, sarcoidosis and connective tissue disorders such as scleromyxedema and lupus erythematosus [18].

Review of the English literature for cases of secondary syphilis with no mucosal or genital lesions and without involvement of palms and soles reveals that most of these cases were characterized by a prominent histiocytic inflammatory infiltrate (Table 1). In standing with the rate

\begin{tabular}{|c|c|c|c|c|c|c|c|c|}
\hline \multirow{2}{*}{ Reference } & \multirow{2}{*}{$\begin{array}{l}\text { Age I } \\
\text { Sex }\end{array}$} & \multirow{2}{*}{$\begin{array}{l}\text { Duration } \\
\text { (weeks) }\end{array}$} & \multirow{2}{*}{$\begin{array}{c}\text { Clinical } \\
\text { presentation }\end{array}$} & \multirow{2}{*}{$\begin{array}{l}\text { Preceding } \\
\text { genital } \\
\text { lesions }\end{array}$} & \multirow{2}{*}{ Distribution } & \multirow{2}{*}{ Lymphadenopathy } & \multicolumn{2}{|c|}{ Histopathology } \\
\hline & & & & & & & Pattern & Cellular components \\
\hline $\begin{array}{l}\text { Biro et al. } \\
1968 \text { [26] }\end{array}$ & $52 / \mathrm{M}$ & 12 & $\begin{array}{c}\text { Papules, plaques, } \\
\text { nodules }\end{array}$ & None & $\begin{array}{l}\text { Chest, back, } \\
\text { shoulders }\end{array}$ & $\begin{array}{l}\text { Axillary, postauricular, } \\
\text { antecubital, inguinal }\end{array}$ & $\begin{array}{l}\text { Perivascular infiltrate, non- } \\
\text { necrotizing granuloma }\end{array}$ & $\begin{array}{l}\text { Lymphocytes, plasma } \\
\text { cells histiocytes }\end{array}$ \\
\hline $\begin{array}{l}\text { Baum et al. } \\
1983 \text { [21] }\end{array}$ & $58 / \mathrm{M}$ & 4 & Papules, nodules & None $^{*}$ & $\begin{array}{c}\text { Face, neck, chest, } \\
\text { back, groin }\end{array}$ & None & \multicolumn{2}{|c|}{ Biopsy not performed } \\
\hline $\begin{array}{l}\text { Baum et al. } \\
1983[21]\end{array}$ & $59 / \mathrm{M}$ & $>3$ & Nodules & None & $\begin{array}{c}\text { Neck, axillae, lower } \\
\text { mid-back, inguinal } \\
\text { areas }\end{array}$ & Not reported & $\begin{array}{l}\text { Periadnexal, perivascular } \\
\text { infiltrate, mild interface } \\
\text { dermatitis }\end{array}$ & $\begin{array}{l}\text { Lymphocytes, histiocytes, } \\
\text { plasma cells, multi- } \\
\text { nucleated histiocytes }\end{array}$ \\
\hline $\begin{array}{l}\text { Baum et al. } \\
1983[21]\end{array}$ & $52 / \mathrm{M}$ & $<2$ & Nodules & None $^{*}$ & $\begin{array}{c}\text { Face, neck, chest, } \\
\text { shoulders }\end{array}$ & Not reported & \multicolumn{2}{|c|}{ Biopsy not performed } \\
\hline $\begin{array}{l}\text { Hodak et al. } \\
1987[23]\end{array}$ & $66 / \mathrm{M}$ & 8 & Nodules & None & $\begin{array}{c}\text { Face, neck, scalp, } \\
\begin{array}{c}\text { upper extremities, } \\
\text { ear lobes }\end{array}\end{array}$ & $\begin{array}{l}\text { Cervical, axillary, } \\
\text { inguinal }\end{array}$ & $\begin{array}{c}\text { Dense mid- to deep dermal } \\
\text { infiltrate with formation of } \\
\text { follicles }\end{array}$ & $\begin{array}{c}\text { Lymphocytes, histiocytes, } \\
\text { eosinophils, neutrophils, } \\
\text { plasma cells }\end{array}$ \\
\hline $\begin{array}{l}\text { Papini et al. } \\
1998[24]\end{array}$ & $23 / M$ & 4 & $\begin{array}{c}\text { Papules, plaques, } \\
\text { nodules }\end{array}$ & Yes & Chest, abdomen & All superficial & $\begin{array}{l}\text { Dense dermal infiltrate with } \\
\text { perivascular accentuation, } \\
\text { swollen endothelial cells, } \\
\text { vessel wall infiltration by } \\
\text { lymphocytes or plasma } \\
\text { cells }\end{array}$ & $\begin{array}{c}\text { Lymphocytes, plasma } \\
\text { cells, histiocytes, } \\
\text { multinucleated histiocytes, } \\
\text { eosinophils }\end{array}$ \\
\hline $\begin{array}{l}\text { F o n s e c a } \\
\text { et al. } 1999 \\
{[22]}\end{array}$ & $42 / \mathrm{M}$ & 16 & Plaques & None $^{*}$ & $\begin{array}{l}\text { Face, trunk, } \\
\text { extremities }\end{array}$ & None & $\begin{array}{c}\text { Dense dermal infiltrate, } \\
\text { non-necrotizing } \\
\text { granulomas, perineural, } \\
\text { perivascular accentuation, } \\
\text { endothelial cell hyperplasia }\end{array}$ & $\begin{array}{l}\text { Perivascular epithelioid } \\
\text { and multinucleated } \\
\text { histiocytes, lymphocytes, } \\
\text { plasma cells }\end{array}$ \\
\hline $\begin{array}{l}\text { ul Bari and } \\
\text { Raza 2006 } \\
{[19]}\end{array}$ & $29 / F$ & 3 & Papules, nodules & None & Face & Cervical & Perivascular infiltrate & Plasma cells \\
\hline $\begin{array}{l}\text { Brar et al. } \\
2007 \text { [28] }\end{array}$ & 28/M & 4 & $\begin{array}{c}\text { Papules, plaques, } \\
\text { nodules }\end{array}$ & None & $\begin{array}{c}\text { Face, upper } \\
\text { chest, back, upper } \\
\text { extremities }\end{array}$ & $\begin{array}{c}\text { Cervical, axillary, } \\
\text { inguinal, epitrochlear }\end{array}$ & $\begin{array}{c}\text { Dense dermal infiltrate, } \\
\text { non-necrotizing granulomas }\end{array}$ & $\begin{array}{c}\text { Epithelioid histiocytes, } \\
\text { plasma cells, lymphocytes }\end{array}$ \\
\hline $\begin{array}{l}\text { Tsai et al. } \\
2007 \text { [29] }\end{array}$ & 49/M & 4 & Plaques, nodules & None & $\begin{array}{c}\text { Trunk, extremities, } \\
\text { face }\end{array}$ & Cervical, axillary & $\begin{array}{l}\text { Lichenoid dermatitis, and } \\
\text { dense dermal perivascular } \\
\text { and periadnexal, loose } \\
\text { granulomas }\end{array}$ & $\begin{array}{c}\text { Plasma cells, histiocytes, } \\
\text { lymphocytes }\end{array}$ \\
\hline $\begin{array}{l}\text { L a n jo u w } \\
\text { et al. } 2009 \\
{[30]}\end{array}$ & $20 / M$ & 5 & Papules, nodules & None & $\begin{array}{l}\text { Face, trunk, } \\
\text { extremities }\end{array}$ & Inguinal & $\begin{array}{l}\text { Dense dermal infiltrate with } \\
\text { perivascular accentuation, } \\
\text { non-necrotizing granulomas }\end{array}$ & $\begin{array}{l}\text { Lymphocytes, plasma cells, } \\
\text { eosinophils, histiocytes, } \\
\text { multinucleated histiocytes }\end{array}$ \\
\hline $\begin{array}{l}\text { Moon et al. } \\
2009 \text { [20] }\end{array}$ & $38 / \mathrm{M}$ & 26 & $\begin{array}{l}\text { Single nodular } \\
\text { plaque }\end{array}$ & None & Left areola & None & $\begin{array}{l}\text { Dense dermal infiltrate } \\
\text { with formation of } \\
\text { follicles, exocytosis and } \\
\text { granulomatous infiltrate }\end{array}$ & $\begin{array}{l}\text { Heavy lymphohistiocytic } \\
\text { infiltrate, eosinophils, } \\
\text { neutrophils, plasma cells }\end{array}$ \\
\hline $\begin{array}{l}\text { Jang et al. } \\
2011 \text { [25] }\end{array}$ & $46 / \mathrm{M}$ & 4 & Single nodule & None & Scalp & Not reported & $\begin{array}{l}\text { Dermal interstitial infiltrate } \\
\text { with perivascular and } \\
\text { periadnexal accentuation }\end{array}$ & $\begin{array}{l}\text { Lymphocytes, plasma } \\
\text { cells }\end{array}$ \\
\hline
\end{tabular}


Citation: Lee GL, Gru AA, Wong HK, Nagarajan P (2015) Granulomatous Syphilis: A Pattern to Remember. Case Report and Review of Literature. Clin Microbial 4: 184. doi:10.4172/2327-5073.1000184

\begin{tabular}{|c|c|c|c|c|c|c|c|c|}
\hline $\begin{array}{l}\text { Glatz et al. } \\
2013[15]\end{array}$ & $21 / F$ & 8 & $\begin{array}{c}\text { Patches, } \\
\text { ulcerated nodules }\end{array}$ & None & $\begin{array}{l}\text { Face, neck, upper } \\
\text { trunk, upper arms }\end{array}$ & None & $\begin{array}{l}\text { Interface dermatitis, non- } \\
\text { necrotizing granulomas }\end{array}$ & $\begin{array}{c}\text { Non-necrotizing } \\
\text { granulomas, } \\
\text { multinucleated histiocytes, } \\
\text { eosinophils, plasma cells }\end{array}$ \\
\hline $\begin{array}{l}\text { Liu and Ma } \\
2014 \text { [27] }\end{array}$ & $32 / \mathrm{M}$ & 12 & Papules, nodules & None & $\begin{array}{l}\text { Face, trunk, } \\
\text { extremities }\end{array}$ & None & Dense dermal infiltrate & $\begin{array}{l}\text { Plasma cells, } \\
\text { lymphocytes, histiocytes, } \\
\text { multinucleated histiocytes }\end{array}$ \\
\hline $\begin{array}{l}\text { Rysgaard } \\
\text { et al. } 2014 \\
{[16]}\end{array}$ & $62 / \mathrm{M}$ & $<2$ & Papules, nodules & None* & $\begin{array}{l}\text { Trunk, upper } \\
\text { extremities }\end{array}$ & Not reported & $\begin{array}{c}\text { Perivascular and } \\
\text { periadnexal infiltrate, non- } \\
\text { necrotizing granuloma }\end{array}$ & $\begin{array}{l}\text { Histiocytes, lymphocytes, } \\
\text { plasma cells }\end{array}$ \\
\hline $\begin{array}{l}\text { Current } \\
\text { case }\end{array}$ & $44 / F$ & 4 & $\begin{array}{c}\text { Papules, plaques, } \\
\text { nodules }\end{array}$ & Yes & $\begin{array}{l}\text { Face, neck, chest, } \\
\text { back, upper } \\
\text { extremities }\end{array}$ & None & $\begin{array}{l}\text { Perivascular infiltrate, } \\
\text { focal interface dermatitis, } \\
\text { endothelial swelling and } \\
\text { focal vasculitis }\end{array}$ & $\begin{array}{l}\text { Histiocytes, lymphocytes, } \\
\text { rare plasma cells } \\
\text { and eosinophils, } \\
\text { multinucleated histiocytes }\end{array}$ \\
\hline
\end{tabular}

Table 1: Previously reported cases of secondary syphilis with no mucosal ulcers, genital lesions or palmar / plantar involvement. * Prior history of treated syphilis, $¥$ history of HIV

of reported cases of syphilis, there was a male predominance with only 3 of the patients, including the current case being female [15,19]. In most patients, the duration of skin lesions before presentation was 12 weeks or less, with exception of one patient [20]. The lesions range from plaques to papules to nodules and are rarely ulcerated [15]. Face, upper trunk and upper extremities are the commonly affected areas, while lower back and intertriginous areas are rarely affected [21]. In most patients, the rash was either asymptomatic or pruritic [22-24]; however, our patient complained of associated pain. While most patients presented with multiple skin lesions, two patients presented with single isolated lesions, which makes the diagnosis almost impossible without histologic examination and a high-degree of suspicion [20,25]. Lymphadenopathy was not a standard feature and less than half of the patients were reported to have any lymph node enlargement. Three patients had prior history of previously treated syphilis $[16,21]$, while one had recently been diagnosed with HIV and hepatitis C [22]. Most of the patients did not display other signs of secondary syphilis. However, 3 patients, including ours had unilateral or bilateral uveitis $[22,26]$, while 2 patients had generalized maculopapular rash before the development of papules and nodules [21,27]. One patient had flulike symptoms before development of cutaneous lesions [28]. While the typical moth-eaten pattern of alopecia was not noted in any of the patients, lateral alopecia of the eyebrows, complete loss of eyebrows and alopecia of eyelid margins were seen $[19,22,28]$.

Biopsies were performed in all patients except two patients that had a prior diagnosis of syphilis and many of these patients were at low-risk for sexually transmitted diseases. Perivascular infiltrate of epithelioid histiocytes, admixed with varying numbers of lymphocytes, plasma cells and multi-nucleated histiocytes was the most common histologic feature. While at least scattered plasma cells were seen in all cases, prominence of plasma cells was noted in only 2 cases $[19,25]$. Rarely, dense dermal lymphocyte-predominant inflammatory infiltrate with formation of follicles may be seen and were diagnosed as pseudolymphomatous processes [20,23].

The histiocytes frequently formed loose, non-necrotizing granulomas around the dermal vasculature. In most cases, neither the blood vessels, nor the endothelial cells were affected. However, in some cases including ours, there was endothelial swelling, hyperplasia and mononuclear cells within vessel walls. Though frank vasculitis may not be evident, perivascular fibrinous exudate, admixed with cellular debris may simulate necrosis. Perineural inflammation was seen only in one case, due to which it was initially misdiagnosed as leprosy [22]; in our case, there was perineural accentuation of the inflammatory infiltrate. In some cases, histiocytes were inconspicuous [19,25-30].

Granulomatous inflammatory infiltrate is considered to be an indicator of early secondary syphilis and most patients with exception of two presented within 12 weeks of onset of their skin lesions [16]. In the late stages, after resolution of the inflammation, pigmentary alterations may predominate [7]. Nevertheless, with the re-emergence of syphilis, it is important to remember syphilis as a possibility in unusual clinical scenarios, especially because of the relative ease of treatment. It should be included in the list of clinical differential diagnoses of disseminated erythematous and indurated papulo-nodular cutaneous lesions, even in the absence of risk factors and other characteristics of typical secondary syphilis, such as palmar / plantar involvement, mucosal lesions, lymphadenopathy or papulosquamous eruption.

\section{References}

1. Patton ME, Su JR, Nelson R, Weinstock H; Centers for Disease Control and Prevention (CDC) (2014) Primary and secondary syphilis--United States, 20052013. MMWR Morb Mortal Wkly Rep 63: 402-406.

2. Centers for Disease Control and Prevention (CDC) (2006) Primary and secondary syphilis--United States, 2003-2004. MMWR Morb Mortal Wkly Rep 55: 269-273.

3. McNabb SJ, Jajosky RA, Hall-Baker PA, Adams DA, Sharp P, et al. (2007) Summary of notifiable diseases --- United States, 2005. MMWR Morb Mortal Wkly Rep 54: 1-92

4. Corigliano MA (2004) Syphilis In: F. F, editor. Ferri's clinical advisor: instant diagnosis and treatment. St Louis Mosby. pp. 796-800.

5. Hicks C (2004) Syphilis. In: Rakel R. E. BET, editor. Conn's current therapy 56 ed. Philadelphia: W.B. Saunders. pp. 781-783.

6. Mullooly C, Higgins SP (2010) Secondary syphilis: the classical triad of skin rash, mucosal ulceration and lymphadenopathy. Int J STD AIDS 21: 537-545.

7. Baughn RE, Musher DM (2005) Secondary syphilitic lesions. Clin Microbiol Rev 18: $205-216$.

8. Lautenschlager S (2006) Cutaneous manifestations of syphilis : recognition and management. Am J Clin Dermatol 7: 291-304.

9. Mattei PL, Beachkofsky TM, Gilson RT, Wisco OJ (2012) Syphilis: a reemerging infection. Am Fam Physician 86: 433-440.

10. Calonje E NS, Bunker C, Francis N, Chaux A, Cubilla AC (2012) Syphilis. In W.R. S, editor. McKee's pathology of skin: Elsevier Saunders. pp. 465-472.

11. Wu SJ, Nguyen EQ, Nielsen TA, Pellegrini AE (2000) Nodular tertiary syphilis mimicking granuloma annulare. J Am Acad Dermatol 42: 378-380.

12. Perry HO, Lofgren RK (1984) Secondary and tertiary syphilis presenting as sarcoidal reactions of the skin. Cutis 34: 253-255, 257-8.

13. Revathi TN, Bhat S, Asha GS (2011) Benign nodular tertiary syphilis: a rare presenting manifestation of HIV infection. Dermatol Online J 17: 5

14. Abell E, Marks R, Jones EW (1975) Secondary syphilis: a clinico-pathological review. Br J Dermatol 93: 53-61.

15. Glatz M, Achermann Y, Kerl K, Bosshard PP, Cozzio A (2013) Nodular secondary syphilis in a woman. BMJ Case Rep 2013. 
Citation: Lee GL, Gru AA, Wong HK, Nagarajan P (2015) Granulomatous Syphilis: A Pattern to Remember. Case Report and Review of Literature. Clin Microbial 4: 184. doi:10.4172/2327-5073.1000184

Page 5 of 5

16. Rysgaard C, Alexander E, Swick BL (2014) Nodular secondary syphilis with associated granulomatous inflammation: case report and literature review. J Cutan Pathol 41: 370-379.

17. Kahn LB, Gordon W (1971) Sarcoid-like granulomas in secondary syphilis. A clinical and histopathologic study of five cases. Arch Pathol 92: 334-337.

18. Balagula Y, Mattei PL, Wisco OJ, Erdag G, Chien AL (2014) The great imitator revisited: the spectrum of atypical cutaneous manifestations of secondary syphilis. Int J Dermatol 53: 1434-1441.

19. ul Bari A, Raza N (2006) Secondary syphilis clinically mimicking pseudolymphoma of the face. Dermatol Online J 12: 20.

20. Moon HS, Park K, Lee JH, Son SJ (2009) A nodular syphilid presenting as a pseudolymphoma: mimicking a cutaneous marginal zone B-cell lymphoma. Am J Dermatopathol 31: 846-848.

21. Baum EW, Bernhardt M, Sams WM Jr, Alexander WJ, McLean GL (1983) Secondary syphillis. Still the great imitator. JAMA 249: 3069-3070.

22. Fonseca E, García-Silva J, del Pozo J, Yebra MT, Cuevas J, et al. (1999) Syphilis in an HIV infected patient misdiagnosed as leprosy. J Cutan Pathol 26: 51-54.

23. Hodak E, David M, Rothem A, Bialowance M, Sandbank M (1987) Nodular secondary syphilis mimicking cutaneous lymphoreticular process. J Am Acad
Dermatol 17: 914-917.

24. Papini M, Bettacchi A, Guiducci A (1998) Nodular secondary syphilis. Br J Dermatol 138: 704-705.

25. Jang YH, Sim JH, Kim YC, Lee ES (2011) Single nodular lesion on the scalp: a quiz. Diagnosis: nodular secondary syphilis. Acta Derm Venereol 91: 491-494.

26. Biro L, Hill AC, Kuflik EG (1968) Secondary syphilis with unusual clinical and laboratory findings. JAMA 206: 889-891.

27. Liu J, Ma D (2014) Disseminated nodular and granulomatous secondary syphilis. J Dermatol 41: 650-651.

28. Brar BK, Mehta V, Raj RT (2007) Nodular secondary syphilis mimicking cutaneous lymphoreticular process. Indian J Dermatol Venereol Leprol 73: 437-438.

29. Tsai KY, Brenn T, Werchniak AE (2007) Nodular presentation of secondary syphilis. J Am Acad Dermatol 57: S57-58.

30. Lanjouw E, van der Meijden WI, den Hollander JC, Neumann HA (2009) Unusual late nodular presentation of secondary syphilis. Int J STD AIDS 20: 271-273. 